\title{
Rational use of natural resources and provision of the population with the necessary food resources
}

\author{
N.A.Koryakina ${ }^{1, *}$, V.A. Pomozova ${ }^{2}$, T.F. Kiseleva ${ }^{3}$, N.A. Frolova ${ }^{4}$, and N.V. Shkrabtak ${ }^{4}$ \\ ${ }^{1}$ Far East Higher Combined Arms Command of the Order of Zhukov School, st. Lenin, 158, \\ Blagoveshchensk, Russia \\ ${ }^{2}$ Ural State University of Economics, st. 8 March / Narodnaya Volya, 62/45, Yekaterinburg \\ ${ }^{3}$ Kemerovo State University, st. Krasnaya, 6, Kemerovo, Russia \\ ${ }^{4}$ Amur State University, Ignatievskoe shosse, 21, Blagoveshchensk, Russia
}

\begin{abstract}
Forest natural resources are classified as renewable biological resources. The forests of Russia are a unique ecological system that makes up about $25 \%$ of all forest resources of the planet. The main product produced in the exploitation of forests is, of course, timber. But in addition to wood, they also have a variety of non-wood (side) resources: berries, forest mushrooms, nuts, fruits, medicinal herbs, etc., which have enormous social and economic value. The article provides an overview of the food forest resources of the Far Eastern region and the formation of demand factors for products made on the basis of wild plant raw materials. The development in the Far East of the sphere of harvesting and processing of wild-growing food resources is one of the promising areas in the rational use of natural resources, which, in turn, will serve as an incentive for the development of new areas in related industries: food, processing, pharmaceutical industry and agro-industrial production.
\end{abstract}

\section{Introduction}

At present, the problem of rational and integrated nature management is given special attention by scientists from different countries. This is due to the fact that the modern approach to the analysis of factors, dynamics, problems and interpretation of economic growth - as the main goal of the country's economic development - presupposes the high importance of nature management, as well as regulation of the process of reproduction of natural resources and preservation of the quality of the natural environment.

The "Concept of sustainable development" is gaining more and more popularity, reinterpreting the concepts of "growth", "economic growth", "development" and the natural environment.

So, in accordance with this Concept, it is necessary to assess not only the growth in the output of goods and services, usually interpreted as GDP growth, but also the change in the value of natural capital. GDP growth, which until recently was set as the main

\footnotetext{
${ }^{*}$ Corresponding author: koryakina.nata1405@yandex.ru
} 
macroeconomic goal, cannot indicate growth in general, if at the same time there is a decrease in the quantity and deterioration of the quality of natural resources, a decrease in natural capital.

A special place in the Concept of sustainable development is occupied by the concept of "rational use of natural resources" as an integral part of "sustainable growth".

Rational use of natural resources is a rather difficult category, because rationality is not considered purely from an economic standpoint and is not evaluated on the basis of such well-known indicators as economic effect or economic efficiency. The modern interpretation of rational nature management is considered simultaneously from three positions: economic, social and environmental.

The main components of rational environmental management are shown in Figure 1. As can be seen from Figure 1, rational environmental management should include both activities aimed at meeting the needs of humans and society as a whole (i.e. production), and activities aimed at conserving natural resources. and activities aimed at creating and maintaining an environmentally friendly natural environment for human health and life [1, 2]. In other words, rational nature management is a system of activities that is designed to ensure the economical and efficient exploitation of natural resources, the optimal mode of their reproduction and the preservation of human health.

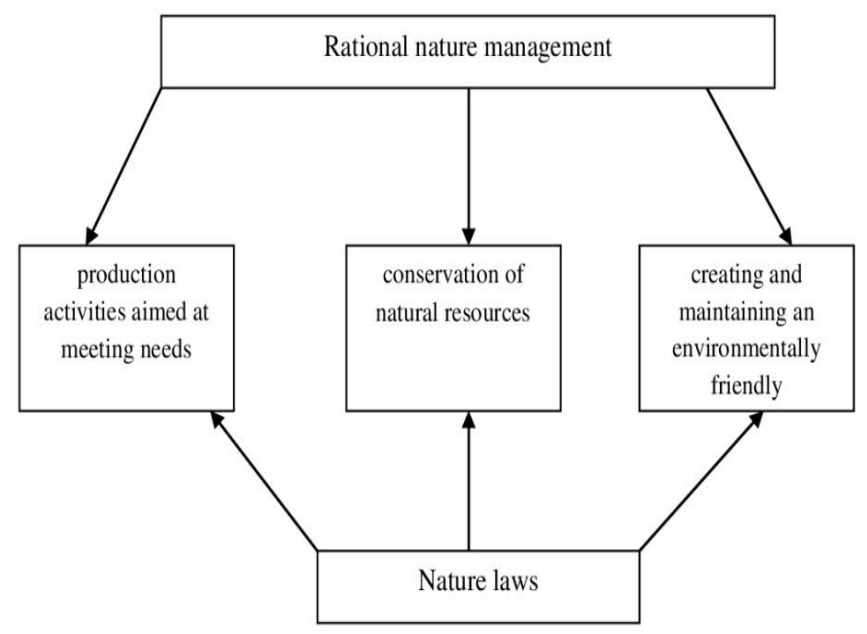

Fig. 1. Main components of rational environmental management.

It seems important that all this activity should be carried out taking into account the laws of nature. In a situation where environmental and economic interests clash, the priority, in our opinion, should remain with the environment. The interaction of man and the natural environment should be based on the priority of the principles of ecological balance.

This, in particular, is one of the features of rational use of natural resources: in the first place it puts the study and conservation of natural resources, and not their use, which is characteristic of the traditional "frontal" economy.

The rational use of natural resources has a direct impact on sustainable growth. So, on the one hand, production activities directly depend on the efficiency of resource development. On the other hand, the quality of the environment, which directly depends on the ways of using natural resources, determines the quality of life, which is one of the final, final indicators of the country's economic development.

One of the basic principles of rational environmental management is environmentally friendly and comprehensive processing of raw materials. 
The use of natural resources can be recognized as rational only if it provides a mode of economical and efficient exploitation of natural resources with the maximum extraction of useful products from them. True rational nature management (that is, nature management focused on all three components, and not just economic indicators) should not lead to drastic changes in the natural resource potential and should not cause profound changes in the natural environment. At the same time, the priority is to comply with the norms of admissibility of impact on nature, based on the requirements of its protection and inflicting the least harm on it.

In our opinion, the priority task for creating such harmonious relations between nature and mankind, which would satisfy both ecological and social and economic needs, is the construction of a mechanism for nature management that ensures full coordination of the interests of the state, society and man in the field of environmental protection and rational use of natural resources. [3].

The formation of such a mechanism should be one of the priority tasks of the state. The market by itself is not able to build such a mechanism, since issues related to the use of natural resources, their reproduction, environmental protection, etc. fall into the "market failures / fiasco" zone. The state should develop norms for the rational use of natural resources, create a system of economic incentives for the implementation of the principles of rational use of natural resources in practical economic activity, ensure the implementation of measures aimed at solving environmental problems and monitoring the state of the natural environment.

As stated above, one of the components of rational nature management is the creation and maintenance of an ecologically favorable environment. This is due to the fact that the main condition for the existence of human civilization is a healthy natural environment with its richest natural resources. At the same time, the natural environment provides the population with food. At the same time, it is very important to know for what period of time and what volumes (reserves) of food raw materials will provide the ever-growing population of the planet with food.

There is an ambivalent attitude on the part of a person and society as a whole to the natural environment: on the one hand, a high-quality and healthy natural environment is a human habitat, it determines such parameters of the quality of life as life expectancy, the level of morbidity. From this position, society is interested in interfering with nature as little as possible. On the other hand, natural resources are the basic economic factor, supplying raw materials for the production of economic benefits. From this position, society is interested in increasing the production of goods to meet its ever-growing needs. In connection with such a dual assessment of the importance of the natural environment for humans, conflicting goals arise: to satisfy the needs of society as fully as possible, increasing the production of goods and services, while causing minimal damage to the natural environment [4].

This contradiction is also reflected in the Concept of Sustainable Development. Specifically, Principle 8 states: "To achieve sustainable development and a better quality of life for all people, governments must limit and eliminate unsustainable production and consumption patterns and encourage appropriate demographic policies."

The annual growth of the world's population is increasing, according to various estimates, by $1.2-1.4 \%$, and according to the forecasts of UN experts in 2030 it will amount to approximately 8.6 billion people, and by 2050 - almost 10 billion. a person consumes on average about $800 \mathrm{~g}$ of food and $2000 \mathrm{ml}$ of water only for drinking water supply.

Today, the population of our planet on average per day consumes more than 4 million tons of food, while the rate of agricultural production is significantly lagging behind the rate of population growth. The situation is aggravated by various natural disasters, crop failure, as well as the uneven distribution of the population and corresponding natural 
resources over the Earth's surface. As a result, the problem of non-renewable natural resources arises, which in the future can lead to a number of problems: poverty, hunger, and a shortage of drinking water.

There is a certain contradiction between the capabilities of the natural environment to provide humanity with water and food and the needs of the latter for food, as well as a contradiction between the use of natural resources and environmental sustainability [5]. The problem is aggravated by the fact that a person needs a certain set of fats, proteins, carbohydrates, microelements, etc. in order to fully function and maintain a certain quality of life.

In the Russian Federation, rational norms for the consumption of food products that meet modern requirements for a healthy diet have been approved by the Ministry of Health. In particular, according to these recommendations, the consumption rate of fresh fruits and berries per person is $100 \mathrm{~kg}$ per year.

Actual data show that the consumption of this group of products lags behind the standards and averages $62 \%$ of the recommended rate, i.e. on average, a person consumes only two-thirds of the required volume. This deviation from the recommended norms affects the quality of food and, as a result, the quality of life of Russians.

One of the ways to solve this problem can be the use of wild plants for food.

\section{Materials and methods}

The study used data for the Far East region for the period 2016-2020. The review of food forest resources concentrated in the territory of the Far East is made. The theoretical basis of the research is formed by regulatory documents and scientific publications. The information base is the data of the Federal State Statistics Service and the Unified Interdepartmental Information and Statistical System. The research used methods: analytical and statistical.

\section{Results and discussion}

Most of the wild plants are found in forests. In particular, the forests of Russia are a unique ecological system, occupying 1.2 billion hectares and containing about $25 \%$ of all forest resources of the planet. In addition to the timber reserves themselves, they also have other non-timber (side) various resources: berries, forest mushrooms, nuts, fruits, medicinal herbs, etc., which have enormous social and economic value.

All over the world, incl. and in Russia, the use of wild products grown in natural conditions by nature itself is gaining special popularity. There are a number of explanations for this.

Firstly, biologically active and tonic substances contained in wild plants have a positive effect on the human immune system and have immunostimulating and therapeuticfunctional properties. Such substances include vitamins, easily digestible carbohydrates, tannins and pectin substances, organic acids, and trace elements.

Secondly, wild plants were grown without the use of fertilizers, chemicals, in areas not affected by anthropogenic and man-made impacts, which makes them especially attractive for consumers focused on a healthy lifestyle and organic food. Thirdly, wild plants are often endemic, to the consumption of which people living in this area are adapted [6].

In addition, wild plants make it possible to expand the range of food products, which is especially important in regions of risky farming.

The reserves of the main species of wild plants in Russia are quite large [7]. So, according to the Federal Forestry Agency, the operational reserves of only the most 
common species of wild plants amount to 7.4 million tons, and biological reserves - 13.4 million tons, which, with a population of 146.9 million people, is more than $50 \mathrm{~kg}$. per person per year.

For the purpose of harvesting food forest resources and collecting medicinal plants, 342 forest plots with a total area of 2 million hectares have been leased to date. Most of them are concentrated in the Far East (Primorsky Krai - 697 thousand hectares, Khabarovsk Krai - 312 thousand hectares) and in Siberia (Tomsk region - 444 thousand hectares, the Republic of Buryatia - 123 thousand hectares, Irkutsk region - 112 thousand hectares).

The following main food resources are collected on leased forest plots, in million $\mathrm{kg}$ : nuts - 7.2; berries - 1.4; medicinal plants - 0.7; mushrooms - 0.5; birch sap - 0.4 .

In general, about 10.2 million $\mathrm{kg}$ of wild plants are harvested annually, which, given the available reserves of 7.4 million tons, is less than $0.15 \%$. Even if we imagine that the volume of illegal and nowhere non-fixed collection of wild plants is the same, then even in this case, less than $1 \%$ of their operational reserves are used.

The above calculations allow us to conclude that Russia has sufficient operational reserves of forest wild plants. But, unfortunately, the processing industries for such resources have extremely low rates of development.

In the context of the growing demand for organic food, as well as the inability of domestic agriculture to fully meet the needs of the population, the procurement and processing of non-wood food forest resources and medicinal plants is seen as a promising sector of the economy with great potential for its development.

In turn, the development of this industry can cause a multiplier effect, stimulating the growth of production in related industries - food, processing, pharmaceutical industry and in the agro-industrial complex.

This will make it possible to have a positive impact, both on individual industries and on the economy as a whole, as well as play an important role in solving social problems.

In some regions, for example, in the Far East of Russia, the procurement of food nontimber resources may be a priority development path for forest use in certain forest areas and play a special role, taking into account the availability of forest resources [8].

In the Far East, forests have one of the highest levels of biodiversity. At the same time, the use of food non-wood forest products allows them to preserve their important ecological function, providing an opportunity for economic development in areas of great ecological and social importance. Yield and productivity indicators for the main types of berries are shown in table 1.

Table 1. Indicators of yield and productivity for the main types of berries in the Far East, thousand tons.

\begin{tabular}{|c|c|c|}
\hline \multirow{2}{*}{ Berry } & \multicolumn{2}{|c|}{ All over the territory } \\
\cline { 2 - 3 } & biological crop & productivity \\
\hline Actinidia kolomikta & 2 & 1 \\
\hline Vaccínium vitis-idaea & 455 & 275 \\
\hline Vítisamurensis & 3 & 2 \\
\hline Vacciniumuliginosum & 290 & 140 \\
\hline Oxycoccus & 260 & 135 \\
\hline Schisandrachinensis & 3 & 2 \\
\hline Vacciniummyrtillus & 35 & 20 \\
\hline
\end{tabular}

As can be seen from the data presented in Table 1, in the territory of the Far East, the total yield for the main types of berries alone is 1,048 thousand tons. With the number of 
inhabitants of this region as of January 1, 2021, 8 million 124 thousand - potentially, each of them can have about $130 \mathrm{~kg}$ of berries annually.

The Far East has large reserves of wild-growing plant raw materials [9, 10, 11]. High demand for products made from such raw materials is formed due to its special quality characteristics (Fig. 2).

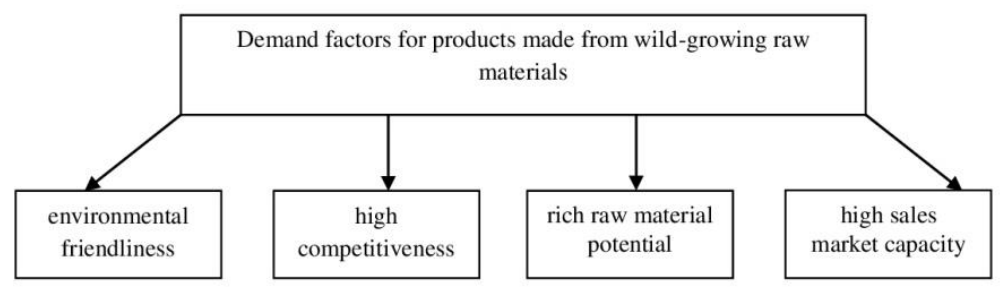

Fig. 2.Demand factors for products based on wild plant raw materials.

As can be seen from Figure 2, the main factors shaping the high demand for products made on the basis of wild plant raw materials are:

- environmental friendliness (pesticides and agrochemicals are not used when growing wild plants),

- high competitiveness (natural and climatic characteristics of the Far East do not allow agriculture to fully meet food needs and, at the same time, create conditions for the growth of endemic plants),

- raw material potential (allows you to create small-scale and, in the future, serial production of products from similar raw materials),

- high sales market capacity (proximity to densely populated Asian countries).

These products are in demand both in the domestic market and in the markets of the member states of the Eurasian Economic Union, as well as third countries, including China and other countries of the Asia-Pacific region, whose residents traditionally use wild plants for food.

\section{Conclusions}

The high demand, as it is seen, ensures the economic attractiveness of this industry in the constituent entities of the Far East.

Unfortunately, the collection and processing of non-wood food resources is extremely poorly developed, rich forest resources are practically not used: the collection of wild berries does not yet exceed $1 \%$ of the biological reserves.

At the same time, of the whole variety of wild berries, the most popular are Chinese magnolia vine, lingonberry, blueberry, cranberry, etc. The rest are used extremely rarely, which is primarily due to their poor knowledge.

Thus, in the territory of the Far East there is a large raw material potential of wildgrowing food raw materials and the possibility of its more rational use. At the same time, the proposed model of rational use will solve the problem of providing the population with new products of increased biological value.

\section{References}

1. V.V. Dezhkin, Biological nature management (2004)

2. V.V. Kruglov, Bulletin of the Ural Institute of Economics, Management and Law, 4 (21) (2012) 
3. V.V. Dezhkin, Conceptual and methodological foundations for the restoration and development of biological nature management in rural Russia, 1 (2002)

4. R.I. Naydenova, Fundamental research, 8, 69 (2007)

5. N. I. Erdynieva, Bulletin of VSGUTU, 4 (35), 27 (2011)

6. N. N. Stepakova, Vegetable and wild-growing raw materials of the Far East region as a source of biologically active substances, 1, 78 (2019)

7. FAO Forest Products Yearbook 2016, http: //www.fao.org

8. N. A. Koryakina, Food forest resources of the Far East region, 405 (2020)

9. N.N. Stepakova, International scientific research, 2, 344(2017)

10. P. B. Ryabukhin, Analysis of the state and prospects for the development of the timber industry complex of the Far Eastern Federal District(2013)

11. T. I. Vorobets, Forests of Russia: politics, industry, science, education, materials of the IV scientific and technical conference St. Petersburg (2019) 